\title{
Az elhárító mechanizmusok, a vallásosság és a szomatizáció összefüggései
}

\author{
TERDIK ÉVA* - PAPP GÁBOR - SZTANCSIK VERONIKA \\ Debreceni Egyetem, Bölcsészettudományi Kar, Pszichológiai Intézet, Debrecen
}

(Beérkezett: 2016. február 20., elfogadva: 2017. január 12.)

Elméleti háttér: A vallásossággal kapcsolatos újabb pszichológiai kutatások a vallásosságot coping-mechanizmusként kezelik a betegségekkel való megküzdésnél. Ám a beszámolókban kisebb hangsúlyt kapott az a jelenség, miszerint sok esetben a vallásosság nem pusztán nem járt együtt, hanem kifejezetten negatívan korrelált a betegséghez való alkalmazkodással. Feltételeztük, hogy amit a fent említett kutatások a maladaptív coping hatásának tulajdonítottak, az valójában az elhárító mechanizmusok számlájára írható. Cél: A vizsgálat célja a vallásosság és az elhárító mechanizmusok közötti kapcsolat fennállásának ellenőrzése volt, kitérve a szomatizációra, mint az éretlenebb elhárító mechanizmusokkal szorosan összefüggő jelenségre. Módszerek: A keresztmetszeti kérdőíves kutatásban 308 fő vett részt (32,5\% férfi, 67,5\% nő; átlagéletkor: 28,29 év; szórás: 13,82 év; terjedelem: 14-81 év). A vallásos attitúdformákat a Kritika Utáni Vallásosság Skálával, az elhárító mechanizmusokat a REM-71 kérdőívvel, míg a szomatizációt az SCL-90-R Szomatizáció alskálájával mértük. Eredmények: A vallási attitúdformák előfordulási gyakorisága a Kritika Utáni Vallásosság Skála alapján a következő: „ortodox” 21,8\%, „külső kritika” 39,3\%, „relativizmus” 16,6\%, „második naivitás” 22,4\%. A legfontosabb eredmények azt mutatják, hogy a négy attitúdforma között szignifikáns eltérés mutatkozik az éretlen elhárító mechanizmusok használatában $(\mathrm{F}(3,307)=10,905 ; p<0,001)$ és a szomatizáció mértékében $(\mathrm{F}(3,307)=4,764 ; p=0,003)$. A mediációs elemzés eredményei szerint a szomatizáció és a szimbolikusság közötti kapcsolat az éretlen elhárító mechanizmusok közvetítő hatásának köszönhető $(\beta=-0,11 ; p<0,01)$. Következtetések: A vallásos személyeken belül elkülöníthető két eltérő jellegzetességeket mutató csoport: az „ortodox” vallásosak, akik több éretlen elhárító mechanizmust használnak és nagyobb mértékben szomatizálnak, illetve a „második naivitás" csoportja, akikre kevesebb éretlen hárítás és kisebb mértékú szomatizáció jellemző. Ezek az eredmények felhívják a figyelmet arra, hogy a vallásosságot érdemes differenciáltabban szemlélni a segítő szakmák képviselőinek, és nagyobb hangsúlyt helyezni az éretlenebb elhárítások felismerésére és a szimbolikus feldolgozás elősegítésére az „ortodox” csoportban lelki problémák esetén.

Kulcsszavak: elhárító mechanizmusok, vallási attitúdformák, szomatizáció, Kritika Utáni Vallásosság Skála

\footnotetext{
* Levelező szerzó: Terdik Éva, Debreceni Egyetem Bölcsészettudományi Kar, Pszichológiai Intézet, 4010 Debrecen, Egyetem tér 1. E-mail: evaterdik@gmail.com
} 


\section{Bevezetés}

Az elméleti összefoglalóban a vallásosság és a coping kapcsolatától indulva jutunk el a tanulmány első főbb témájához, a vallásosság és az elhárító mechanizmusok lehetséges összefüggéseihez. Ezt követően kerül bevezetésre a harmadik vizsgált jelenség, a szomatizáció, amely mint elhárító múködés is értelmezhetó, de ugyanakkor tünetcsoport, diagnosztizálható zavar is egyben. Végül David M. Wulff (1997) elméletének összefoglalása olvasható a vallásos attitúdformákról, amely a jelen tanulmányban bemutatott vizsgálatban alkalmazott attitúdskála elméleti alapját képezte.

A vallásosság és a coping. A vallásosság szorongáscsökkentő szerepét eddig fóként olyan empirikus kutatásokban dolgozták fel, amelyek a betegség során aktiválódó megküzdési módokat vizsgálták. A coping speciális altípusaként, vallásos copingként ismert a jelenség. Úgy tartják, hogy a vallás azáltal, hogy értelmezési keretet nyújt az eseményekhez, szociális támaszt biztosít a gyülekezeti tagoknak és elősegíti a kontrollérzet növekedését, a betegek jobb alkalmazkodását segíti, tehát például a gyorsabb gyógyulást (Levin, 1996; Ellison \& Levin, 1998; Siegel, Anderman, \& Schrimshaw, 2001). Bár általában a vallásosság szalutogén jellegét emelték ki a kutatásokban, megfigyelhető volt, hogy a hit bizonyos aspektusai elégtelenebb testi-lelki állapottal jártak együtt (Ellison \& Levin, 1998; Pargament, 1997). Siegel és munkatársai (2001) például megemlítik, hogy a vallásosság akár olyan maladaptív coping stratégiák használatát is elósegítheti, mint amilyen a tagadás.

A coping és az elhárítás egymáshoz való viszonya. Lazarus (1993) a megküzdés fogalma alá sorolja az elhárításokat, bár a két altípus közül nem a hatékonyabbnak vélt problémaközpontú megküzdési stratégiákhoz, hanem az emóciófókuszú osztályhoz csoportosítja őket (Lazarus, 1993). Az elhárító mechanizmusok a pszichodinamikus szakirodalomból ismert olyan stratégiák, amelyeket az ego alkalmaz tudattalanul, hogy a szorongást csökkentse (Gabbard, 2009). Gardner, Holzman, Klein, Linton és Spence (1959) kutatási eredményeik alapján úgy vélik, hogy formai-múködési szempontból nincs különbség az elhárítás, illetve a megküzdés között. Adaptivitásuk csupán azon múlik, hogy adott helyzetben célszerú-e a használatuk, illetve alkalmazásuk mennyire rugalmatlan (Gardner és mtsai, 1959; idézi V. Komlósi és Rózsa, 2001). Lazarus és Gardnerék elképzelésétől eltéróen Cramer (1998) egyértelmúen különválasztja a copingot és az elhárító mechanizmusokat. Véleménye szerint mindkettő adaptációs folyamatnak tekinthetó, mivel az a funkciójuk, hogy megvédjék az egyéneket a nehéz helyzetek emocionális következményeitől. Hiába lehet azonban ugyanaz a kimenetelük (csökkent stressz-szint vagy kisebb mértékú szorongás), mégis a két folyamat legalább három szempontból különbözik. A coping mechanizmusokkal szemben az 
elhárító mechanizmusok tudattalanok, nem szándékosak és a külső valóságot nem változtatják meg (legfeljebb torzítják annak percepcióját) (Cramer, 1998). Az ismertetett coping-elhárítás összefüggések alapján vélhető, hogy a fenti kutatások egy részénél tévesen copingnak tartottak olyan jelenségeket, amelyek inkább az elhárító mechanizmusokhoz kapcsolhatók. Siegel és munkatársai (2001) már fentebb is említett vizsgálatához - amelyben a vallásosság szerepét kutatták a betegséggel való megküzdésben - azért fontos visszatérnünk, mivel ők már nem pusztán a vallásos személyeket vetették össze a nem vallásosakkal, hanem a vallásos személyek csoportján belül megkülönböztettek intrinzik (belülról fakadó) vallásos csoportot és extrinzik (külső) vallásos csoportot. Eredményeik szerint az intrinzik vallásosság jobb alkalmazkodással és testi állapottal járt együtt, mint az extrinzik vallásosság, ahol vagy nem találtak kapcsolatot, vagy pedig negatív irányú volt az együttjárás. Eredményeiket úgy értékelték, hogy a vallásosság copingként van jelen, ám egyes esetekben ez a megküzdés maladaptív, amely főként az extrinzik vallásos csoportra jellemző. Lazarus (1993) modelljét idézve (ahol az elhárító mechanizmusok a coping stratégiák kevésbé hatékony módjai) feltételezhetjük, hogy amit Siegel és munkatársai (2001) maladaptív copingnak aposztrofáltak, az nagyban fedi az elhárító mechanizmusok fogalmát.

A vallásosság kapcsolata az elháritással. Olyan kutatás, amely kifejezetten a vallásosság és az elhárító mechanizmusok elemzését túzte ki célul, meglehetősen kevés született. Tari, Sobhi-Gharamaleki, Hojjati és Alian (2014) kutatásukat úttörőnek tartják a területen. Vizsgálták a vallásos orientáció és az elhárító mechanizmusok típusainak (érett, neurotikus, éretlen) összefüggéseit, és azt találták, hogy a vallásosan orientáltak érettebb elhárító mechanizmusokat használtak, mint a nem vallásos személyek. A vallásos emberek csoportját ebben a vizsgálatban egységesnek tekintették, és nem vették figyelembe, hogy a vallásos attitúdformák különbözőek lehetnek (ld. később). Ezeket az összefüggéseket figyelembe véve árnyaltabb képet kaphatunk a jellemző elhárító múködések minőségéről is.

A szomatizáció kapcsolata a vallásossággal. A szomatizáció „tendencia pszichológiai állapotok vagy lelki tartalmak testi élmények, funkcionális változások vagy szomatikus metaforák formájában való átélésére, konceptualizálására vagy kommunikálására" (Lipowski, 1968; idézi Kulcsár \& Rózsa, 2004,19 . o.), vagyis a szomatizáló egyén betegnek érzi magát annak ellenére, hogy a kórfolyamatra nincs bizonyíték, vagy ha van is, a páciens arra adott válasza eltúlzott (Wise \& Rundell, 2007). A szomatizációs zavar a BNO-10 (1996) szerint a szomatoform rendellenességek csoportjába tartozó (F.45) olyan szorongásos betegség, amely hosszabb időn keresztül számtalan testi tünettel, panasszal jár. Tapasztalataink szerint a vallásos gyülekezetekben többféle módon állhat kapcsolatban a hit és az egészség. Míg 
egyeseknél pozitív ereje lehet a vallásosságnak, a „teljes élet” megélését, az egészség megtartását segíti, másoknál úgy túnik, feloldatlan szorongás, sok szomatikus tünet van jelen, akár a szomatizációs zavar kritériumait is teljesítve. Szubjektív megfigyeléseinket - természetesen - feltételezésként kezeltük, amelyet tudományos igényességgel szerettünk volna megvizsgálni, ez jelen vizsgálatunk másik kiindulópontja. Mivel a vallásosságot inkább a betegségekkel való megküzdéssel kapcsolatban tanulmányozták, a vallásosság és szomatizáció témája nem mondható túlkutatottnak. A vallásosságot és a szomatizációt összevető vizsgálatuk során Ryan, Rigby és King (1993) a következőket találták: az Allport-Ross-féle extrinzik vallásosság, a Batson és Ventis-féle eszközjellegú vallásosság és a Keresztény Vallásos Internalizációs Skála (Christian Religious Internalization Scale) által mért introjekciós vallásosság gyenge pozitív együttjárást mutatott a szomatizáció mértékével. Ezzel szemben az intrinzik, a céljellegú vallásosság és az identifikációs vallásosság a szomatizációval negatívan korrelált (bár az eredmények közül csak a Keresztény Vallásos Internalizációs Skála korrelációi voltak szignifikánsak). Salsman (2002), aki a szomatizációt a Derogatis-féle Tünetlistával (SCL-90-R) mérte, szintén azt találta, hogy az Allport-Rossféle intrinzik vallásosság negatívan korrelál a szomatizációval, míg az extrinzik vallásosság gyenge, pozitív együttjárást mutat vele. Úgy túnik tehát, hogy a vallásosságukat mélyebben megélő személyek kevésbé mutatnak szomatizációs tüneteket, mint azon vallásos személyek, akiknek a transzcendensbe vetett hite kevésbé megfontolt, kevésbé önmagáért való.

A szomatizáció és az elhárítás. Az elhárító szomatizációt az elhárító mechanizmusok elméleti keretén belül, annak egyik (éretlen) típusaként is tárgyalhatjuk, igazodva ezzel Schur (1955; idézi Mentzos, 2009) de- és reszomatizációs, illetve Mitscherlich (1956; idézi Mentzos, 2009) kettős elfojtás elméletéhez. Schur szerint az egyedfejlődés kezdetén a testi-lelki fejlődés mindig a szomatikus és az affektív jelenségek társulásával történik. Ebben az időszakban a csecsemók öröm- és bánatreakciója egész testükön megfigyelhető, tehát a testi választ egyfajta diffúz elhárítási reakcióként lehet értelmezni. A fejlődés későbbi stádiumaiban azonban a korábban csak izomakciókkal kifejezhető élmények belsővé válnak, és a képzelet, gondolatok, érzések vagy beszéd által vezetődnek le. Egyre nagyobb tudatosságról beszélhetünk, hiszen az alacsonyabb rendú testi elhárítást felváltják a magasabb rendú, pszichés elhárítások és védekezési módok - ezt nevezzük deszomatizációnak. Ezzel ellenkező folyamat a reszomatizáció, amikor az egyén szorongáshelyzetben a fejlettebb szintról regrediál a már meghaladott szintre, azaz testi reakciókkal hárítja el szorongását. A jelenség oka az én-funkciók elégtelenségében keresendő (Schur, 1955; idézi Luban-Plozza, Pöldinger \& Kröger, 1994). Mitscherlich kettős elfojtás elmélete Schur felvetésein alapul. 
A modell szerint az egyén először pszichés eszközökkel igyekszik elhárítani a konfliktusokat, ám ha a konfliktus nagysága meghaladja az én elhárító képességét, akkor bekövetkezhet a második fázis, amikor a konfliktus a testi elhárítási folyamatok irányába tolódik át és testi tünetek formájában jelenik meg. Bár Schur koncepcióját Hoffmann és Hochapfel (2000) kifejezetten aktuális modellnek tartják, empirikusan kevésbé alátámasztott ez az elképzelés. Hyphantis és munkatársai (2013) tanulmányukban, melyben az elhárító mechanizmusokat, az affektív temperamentumot és a szomatizációt vetették össze, arról számoltak be, hogy a témát eddig nem vizsgálták. Eredményeik szerint a vizsgálati személyek magas szomatizáció értékeihez főként éretlenebb elhárító mechanizmusok használata kapcsolódott (mint például a projekció, áttolás, autisztikus fantázia és passzív agresszió). Akik pedig alacsonyabb pontot értek el az SCL-90-R szomatizáció alskáláján, túlnyomóan olyan érett elhárító mechanizmusokat használtak, mint az anticipáció, racionalizáció, humor, szupresszió (Hyphantis és mtsai, 2013).

A vallásos attitüdformák. A vallásosság vizsgálatánál Wulff (1997) elméletére alapoztunk, mivel ez a modell jól differenciál a különböző vallásos attitúdformák közt. Ezen felül, egy széles körben alkalmazott mérőeszköz, a Hutsebaut (1996) által megalkotott Kritika Utáni Vallásosság Skála (a továbbiakban KuVS) is erre az elméletre épült. Wulff (1997) szerint az egyéneket - vallásosság szempontjából - két dimenzió alapján négy csoportba lehet sorolni. A függőleges tengely jelöli a transzcendens bevonását, ahol az egyik végpont a transzcendencia realitásként való kezelése (hisz Istenben), míg a másik a vallásos tárgyak realitásának elutasítása (nem hisz Istenben). A vízszintes tengely a vallásos kifejeződési módok (például meggyőződések, képek, rituálék) interpretációjának szimbolikussági fokát ragadja meg. A dimenzió egyik végpontja a szó szerinti (vagy literális) értelmezés, míg a másik a szimbolikus interpretáció. A wulffi modellt (Hutsebaut csoportneveivel) lásd az 1. ábrán. Az ortodox egyének tehát hisznek Istenben és a vallási tanokat szó szerint értelmezik. A külső kritika csoportja is szó szerint értelmez, ám ők elutasítják a transzcendenst. A relativista csoportra már a vallásos tartalmú dogmák szimbolikus, átvitt értelemben való értelmezése jellemző, ám a külső kritika csoportjához hasonlóan ők sem hisznek Istenben. Végül, a második naivitás csoportjába sorolható személyekre a hittételek szimbolikus interpretációja és az Istenben való hit jellemző.

Vizsgálatunkban tehát arra kerestük a választ, hogy milyen összefüggés mutatkozik a vallásosság és az elhárító mechanizmusok között úgy, ha nem pusztán hívő és nem hívő csoportokat vetünk össze, hanem a vallás szimbolikusságát is figyelembe vesszük. Felvetettük továbbá, hogy a szomatizációt érdemes lenne a vallásos attitúdformákkal és az elhárítással együtt is (nem csak külön-külön) vizsgálni. A szomatizációra egyfelől mint elhárító 


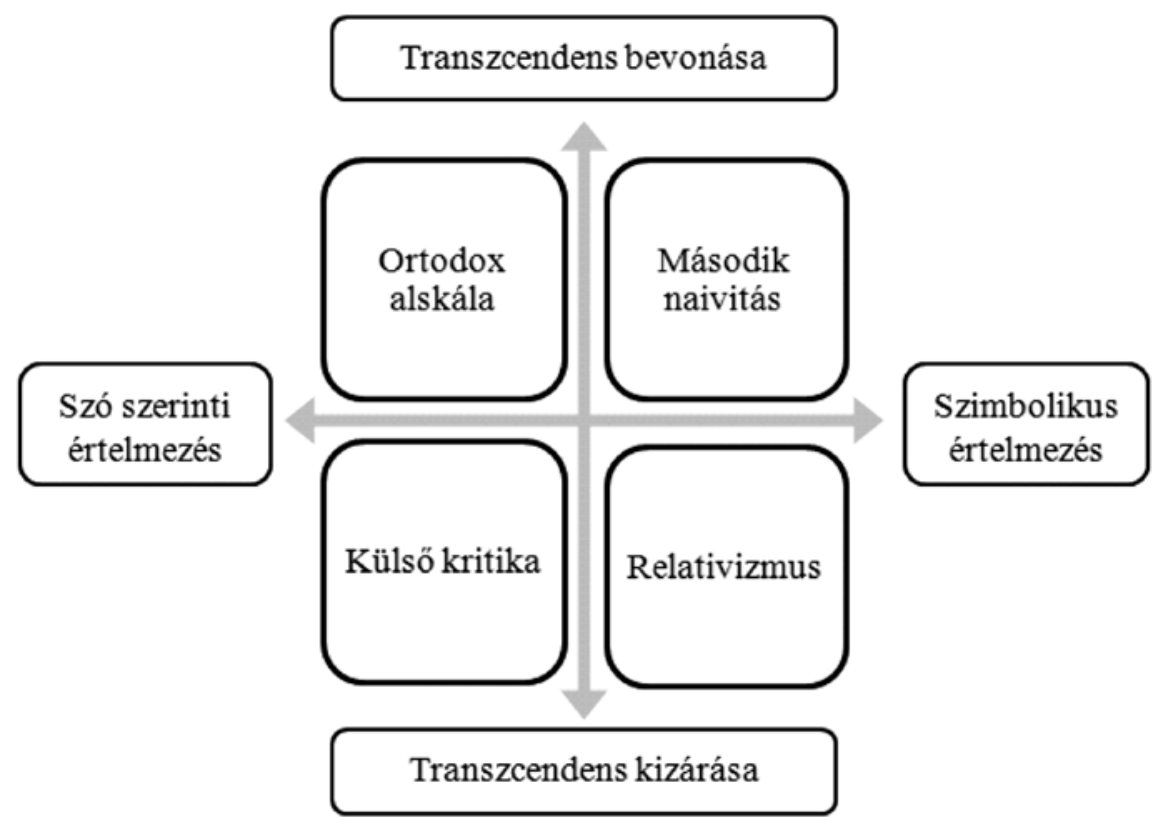

1. ábra. A vallásos attitúdformák (Wulff, 1997, 635. o. nyomán)

mechanizmusra tekintünk (továbbiakban elhárító szomatizáció), amely egy tudattalan belső folyamat, lelki történés. Másfelől viszont a szomatizáció tünet is, testi megjelenése az elhárító szomatizációnak, amely tünetek, ha elérnek egy bizonyos kritériumszintet, már szomatizációs zavarként (F.45.0) jelennek meg. A vizsgálat egyik célkitúzéseként fel kívántuk tárni a különbségeket a különféle vallási attitúddel bírók között az elhárító mechanizmusok és a szomatizáció tekintetében. Felmerült továbbá annak a lehetősége, hogy Ryan és munkatársai (1993), illetve Salsman (2002) korábbi eredményei - miszerint a vallásosság kevésbé belülról fakadó formái és a szomatizáció között összefüggés tapasztalható - valójában az elhárító mechanizmusok közvetítő szerepének köszönhetők. Lehetséges, hogy akik éretlenebbül hárítanak és többet szomatizálnak, ám emellett vallásosak, ők talán a vallásosságukat tudattalanul a feszültségük eliminálására használják, mivel elhárító mechanizmusaik ehhez nem elég érettek. Emellett persze lehetnek olyan vallásos személyek, akiknek a vallásossága önmagáért való, nem pedig eszközjellegú. Esetükben nagyobb fokú énerőre számítunk, amely a vizsgálatban kevesebb éretlen és több érett elhárító mechanizmus, illetve ki- 
sebb mértékú szomatizációban fejeződne ki. A két csoport közötti különbséget a vallásosság szimbolikus vs. szó szerinti értelmezésének eltérésében feltételezzük.

A fentiek alapján a következő hipotéziseket állítottuk fel:

H1: A vallásos tanok szimbolikus értelmezésére való nagyobb hajlam több érett és kevesebb éretlen elhárító mechanizmussal jár együtt.

H2: A vallásos tanok szimbolikusabb értelmezése alacsonyabb szomatizációval jár együtt.

H3: A szimbolikus értelmezés és a szomatizáció közötti kapcsolatban az elhárító mechanizmusok mediáló szerepet töltenek be. A 2. ábrán szemléltetjük azt a kapcsolatrendszert, amelyet a változóink között feltételezünk.

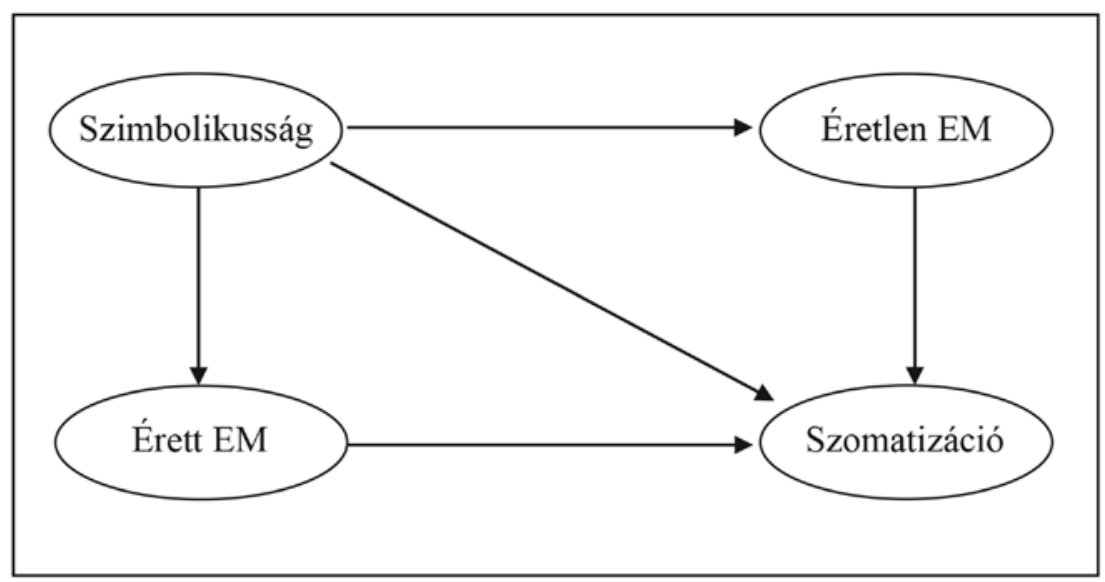

2. ábra. A szimbolikus értelmezésre való hajlam, az éretlen és érett elhárító mechanizmusok, illetve a szomatizáció kapcsolatának elméleti modellje

Megjegyzés: $\mathrm{EM}$ = elhárító mechanizmusok

H4: A transzcendens bevonására való fokozottabb hajlam több érett és kevesebb éretlen elhárító mechanizmussal jár együtt.

H5: A transzcendens bevonására való nagyobb hajlam kisebb mértékú szomatizációval jár együtt.

H6: A transzcendens bevonására való hajlam és a szomatizáció közötti kapcsolatban az elhárító mechanizmusok mediáló szerepet játszanak. A hipotézist összefoglalóan a 3. ábra mutatja be. 


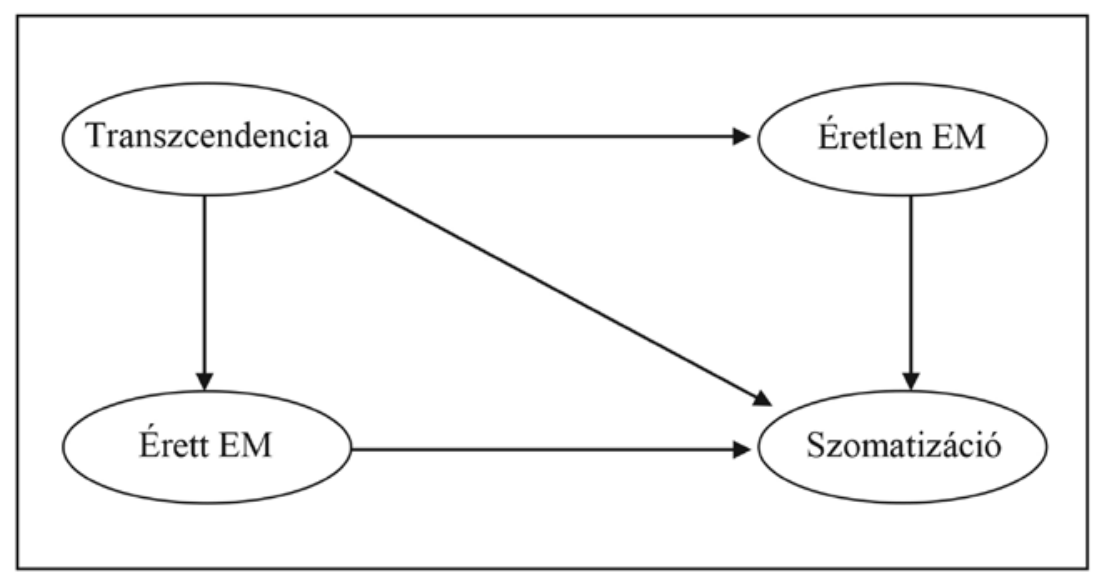

3. ábra. A transzcendencia, az elhárító mechanizmusok és a szomatizáció kapcsolatának elméleti modellje

Megjegyzés: EM = elhárító mechanizmusok

\section{Módszer}

\subsection{Eljárás és minta}

A vizsgálat lebonyolítását a Debreceni Egyetem Pszichológiai Intézetének Intézeti Kutatásetikai Bizottsága jóváhagyta (2016/8).

A keresztmetszeti, kérdőíves vizsgálat mintáját 308 fó alkotta. Az adatgyújtés hozzáférhetőségi mintavétellel, két módon, online felületen és nyomtatott kérdőívcsomag szétosztásával történt. A teszt online verzióját közösségi hálón keresztül terjesztettük, míg a papír-ceruza teszteket a Debreceni Egyetem egyik gyakorló iskolájában vettük fel. A részvétel önkéntes alapon, anonim módon történt és nem vont maga után jutalmat. A 18 év alattiak részvétele a szülók passzív beleegyezéséhez és a diákok hozzájárulásához volt kötve, 18 év felettiek esetén pedig a kitöltő beleegyezése volt szükséges. Mivel a vizsgálati célok nem indokolták speciális minta gyújtését, a részvétel egyetlen kritériuma a 14. életév betöltése volt.

A résztvevők átlagéletkora 28,29 év, szórása 13,81 év volt. A legfiatalabb kitöltő 14 éves, míg a legidősebb 81 éves volt. Nők alkották a minta 67,5\%-át (208 fó, átlagéletkor: 28,75 év, szórás: 13,82 év), így majdnem kétszeres volt a reprezentáltságuk a férfiakhoz képest (100fó, átlagéletkor: 27,33 év, szórás: 13,83 év). Iskolai végzettség szempontjából a minta a következóképpen 
alakult: a legfeljebb 8 általános iskolai osztályt végzettek aránya 35,7\%, a szakmunkásoké 6,5\%, az érettségizetteké 17,2\%, az érettségizett és szakmával rendelkezőké 13,6\% , a diplomásoké 23,4\%, míg a diplomás és szakképzést vagy PhD-t végzett személyek aránya 3,6\%. A vizsgálati személyek vallási, illetve felekezeti hovatartozásának megoszlását, és a vallásosság önbecsült értékének átlagát („Mennyire tartja magát vallásosnak? 1: egyáltalán nem, 7: egészen igen) az 1. táblázatban mutatjuk be.

1. táblázat. A vallási hovatartozás szerinti megoszlás és a vallásosság önbecsült értéke

\begin{tabular}{|c|c|c|c|c|c|}
\hline & \multirow{2}{*}{$\begin{array}{l}\text { Felekezeti } \\
\text { hova- } \\
\text { tartozás } \\
\text { (fó) }\end{array}$} & \multirow[t]{2}{*}{$\begin{array}{l}\text { Százalékos } \\
\text { megoszlás }\end{array}$} & \multicolumn{2}{|c|}{$\begin{array}{l}\text { A vallásosság } \\
\text { önbecsült értéke }\end{array}$} \\
\hline & & & & átlag & szórás \\
\hline \multirow{9}{*}{ 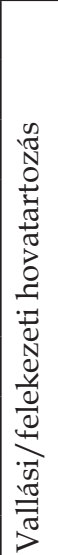 } & Katolikus & 89 & $28,9 \%$ & 4,4 & 1,85 \\
\hline & Református & 111 & $36,0 \%$ & 3,9 & 1,88 \\
\hline & Evangélikus & 4 & $1,3 \%$ & 5,3 & 0,50 \\
\hline & $\begin{array}{l}\text { Más keresztény közösséghez } \\
\text { tartozó }\end{array}$ & 11 & $3,6 \%$ & 5,0 & 2,24 \\
\hline & Agnosztikus & 5 & $1,6 \%$ & 2,6 & 1,82 \\
\hline & Hitetlen & 26 & $8,4 \%$ & 1,2 & 0,40 \\
\hline & Nem szeretne válaszolni & 35 & $11,4 \%$ & 2,7 & 1,61 \\
\hline & Egyéb & 27 & $8,8 \%$ & 2,8 & 1,97 \\
\hline & Összes & 308 & $100 \%$ & 3,6 & 2,02 \\
\hline
\end{tabular}

\subsection{Mérőeszközök}

Kritika Utáni Vallásosság Skála. A skála 33 tételes verziójának segítségével határoztuk meg a vizsgálati személyek vallásos attitúdformáit. Az eredeti kérdóívet (Post-Critical Belief Scale) Hutsebaut (1996) dolgozta ki, amelynek hazai adaptációja Horváth-Szabó (2003) nevéhez köthető. Amint azt a bevezetóben kifejtettük, a teszt segítségével két dimenzió (transzcendens bevonása/elutasítása és szimbolikus/szó szerinti értelmezés) alapján négy csoportba lehet sorolni a kitöltóket (ortodox, külső kritika, relativizmus, második naivitás). A skála 33 tételével való egyetértést a vizsgálati személyek egy hétfokú Likert-skálán jelölhetik (végpontok: 1: egyáltalán nem, 
7: egészen igen). Az alskálák belső konzisztenciája Horváth-Szabó (2003) vizsgálatában az alábbiak szerint alakult: az ortodox alskála Cronbach-a értéke 0,75 , a külső kritikáé 0,80 , a relativizmusé 0,72 , míg a második naivitásé 0,78 volt. A kérdőív kiértékelésének módját később ismertetjük.

REM-71. A Steiner, Araujo és Koopman (2001) által kidolgozott REM-71 (Response Evaluation Measure) egy önkitöltő kérdőív, amelyet a vizsgálati személyek elhárító mechanizmusainak mérésére használtunk. A magyar változattal V. Komlósi és Rózsa (2002) szerzett tapasztalatokat hazai mintán. A kérdőív 71 tételből áll, amelyeknél egy kilencfokú Likert-skálán a vizsgálati személyeknek jelölniük kell egyetértésük mértékét (1: egyáltalán nem értek egyet, 5: nem tudom eldönteni, 9: teljesen egyetértek). A kérdőív 21 elhárító mechanizmus mérésére 66 tételt tartalmaz, illetve ezeken felül négy neutrális tételt, és egy hazugságdetektáló kijelentést is magában foglal. Faktorstruktúrája a következő:

- éretlen elhárítás az acting out, konverzió, kihelyezés (áttolás), disszociáció, fantázia, omnipotencia, passzív agresszió, projekció, represszió, elhárító szomatizáció, hasítás, szublimáció, meg nem történtté tevés, reakcióképzés, visszahúzódás;

- érett elhárítás pedig az altruizmus, a tagadás (az affektus izolációja), a humor, az idealizáció, az intellektualizáció és a szupresszió.

A szublimáció elvárttól eltérő besorolását magyarázhatja, hogy a faktor egyes tételei túlságosan specifikusak, lásd például a 13. tételt: „Amint túljutottam egy igazán nehéz helyzeten, szívesen írok történeteket vagy verseket". A szublimáció ugyanis sokféleképpen végbemehet, nem törvényszerü tehát, hogy a személyek történetek vagy versek írásával eliminálják szorongásukat. A tagadásnál kapott eredmények is ellentmondanak a vártnak, hiszen az érett elhárító mechanizmusokhoz került besorolásra, holott a pszichodinamikus megközelítés rendszerint az éretlen elhárítási módok közé sorolja. V. Komlósi és Rózsa (2001) azt fogalmazza meg, hogy bizonyos élethelyzetekben, például traumák, katasztrófahelyzetek esetén igenis adaptív lehet az ideiglenes tagadás, mivel elősegítheti a gyors alkalmazkodást és reagálást. Ilyen szempontból elképzelhető, hogy nem feltétlenül a tagadást mérik a tételek, hanem a rezilienciát, ami „azon személyes és környezeti tényezőket foglalja magában, amelyek elősegítik a veszélyeztetett életkörülmények ellenére történő sikeres alkalmazkodást, enyhítik a stressz negatív hatásait és lehetôvé teszik a változásokkal való adaptív megküzdést" (Kiss és mtsai, 2015, 94. o.). Ilyenformán értelmet nyerhet, hogy a tagadásnak nevezett elhárító mechanizmus az érett faktorhoz került besorolásra. Az érett és éretlen elhárító mechanizmusok eltérését Steinerék abban látják, hogy mennyire adaptívak, azaz milyen mértékig torzítják a valóságot. A két faktor belső konzisztenciája megfelelőnek mondható mind 
Steiner és munkatársai (2001) szerint (Cronbach-a 0,84 és 0,69), mind pedig saját eredményeink szerint (Cronbach-a 0,87 és 0,83). Az egyes elhárító mechanizmusokhoz tartozó tételek átlaga határozza meg, hogy mennyire jellemző az egyénre az adott elhárító mechanizmus használata. Minél magasabb ez a pontszám, annál inkább jellemző. Az érett és éretlen elhárító mechanizmusok pontszáma pedig a két faktorhoz tartozó elhárító mechanizmusok összegzett pontszámából adódik.

Az SCL-90-R Szomatizáció alskálája. A Derogatis és Cleary által 1977-ben átdolgozott SCL-90-R (Symptom Check-List-90-Revised, Derogatis-féle Tünetlista) egy 90 tételes önkitöltő kérdőív, amely meghatározott pszichés és testi tünetek jelenlétét, azok súlyosságát, illetve a pszichológiai distressz mértékét méri. Az SCL-90-R a következő 9 alskálából áll: szomatizáció, kényszeresség, interperszonális érzékenység, depresszió, szorongás, ellenségesség, fóbia, paranoia és pszichoticizmus. A kitöltóknek 5 fokú skálán kell jelölniük, hogy mennyire zavarta óket az adott tünet az elmúlt egy hétben. A válaszlehetóségek a következók: 0 - egyáltalán nem, 1 - kissé, 2 - mérsékelten, 3 - közepesen, 4 - nagyon (Derogatis \& Cleary, 1977). A Derogatis-féle Tünetlista magyar változatával szerzett tapasztalatok alapján Unoka és munkatársai (2004) a kérdőív megbízhatóságát és érvényességét állapították meg. A vizsgálat céljának megfelelően a szomatizáció alskála került felhasználásra a vizsgálati kérdőívben. Ez információt nyújt a vegetatív szabályozású rendszerekhez (például a szív- és érrendszer, a gasztrointesztinális rendszer, a légzőrendszer) köthető panaszokról és a szorongás testi ekvivalenseinek tartott tünetek (fejfájás, fájdalom és diszkomfortérzet a különbözó izomcsoportokban) jelenlétéról (Derogatis, Rickels \& Rock, 1976). A hazai adaptálás során a szomatizáció skála belső konzisztenciája megfelelő volt mind normatív mintán (Cronbach-a 0,80), mind pedig klinikai mintán (Cronbach-a 0,91) (Unoka és mtsai, 2004). Saját mintánkon a Cronbach-a értéke 0,84 volt.

Demográfiai kérdőív. A kérdőívcsomag utolsó eleme egy demográfiai kérdőív volt, amelyben a vizsgálati személyek nemére, életkorára, legmagasabb iskolai végzettségére és családi állapotára fókuszáló kérdéseken felül az egyének vallásosságához kapcsolódóan is szerepeltek kérdések. Ez utóbbiak megegyeztek a KuVS hazai adaptálását bemutató tanulmányban (Horváth-Szabó, 2003) használtakkal. A vallásosság témakörét három kérdéssel jártuk körül. Egy feleletválasztós kérdéssel tudakoltuk meg a felekezeti, illetve vallási hovatartozást. Rákérdeztünk a templomba vagy gyülekezetbe járás gyakoriságára (1: hetente többször, 2: hetente, 3: csupán különleges alkalmakkor, 4: szinte soha vagy soha), végül egy hétfokú Likert-skálán megválaszolandó kérdés segítségével („Mennyire tartja magát vallásosnak?" 1: egyáltalán nem, 7: egészen igen) mértük fel az önbecsült vallásosság mértékét. 


\subsection{Statisztikai eljárások}

Az elemzéseket - kivéve a KuVS által történő csoportba sorolást - az IBM SPSS Statistics 22.0 programcsomaggal végeztük. A főbb eljárások - az alapvető leíró statisztikai elemzéseken és a Pearson-féle korrelációs elemzéseken túl - az egyszempontos varianciaanalízis (utóelemzésként Tukey-féle HSD-próbával) és a mediációs elemzés volt. Ez utóbbihoz az SPSS-be beépüló PROCESS makrót (Hayes, 2013) használtuk, amelyet kifejezetten mediációs és moderációs elemzésekre fejlesztettek ki.

A KuVS esetében a kutatók körében nincs konszenzus arra vonatkozóan, hogy hogyan értékelendők a kérdőív eredményei. Az attitúdskála eredeti kiértékelési módjával kapcsolatos kritikák hatására született egy újabb eljárás az adatok feldolgozására, azonban ezzel párhuzamosan egyes szerzők (például Dezutter, Soenens, \& Hutsebaut, 2006) még a régi metódust alkalmazzák (Martos, Kézdy, Robu, Urbán, \& Horváth-Szabó, 2009). Vizsgálatunk során az újabb, statisztikai szempontból megalapozottabb eljárást alkalmaztuk, amelyet Martos és munkatársai (2009) dolgoztak ki Fontaine, Duriez, Luyten és Hutsebaut (2003) metódusára alapozva. A módszer lényege, hogy korábbi vizsgálati mintákra számított faktorsúlyok segítségével kalkulálja a dimenziók (transzcendencia és szimbolikusság) értékeit. Azért válik mindez lehetóvé, mivel a skála tételeinek belső struktúrája mintától függetlenül stabilnak bizonyult. A kiértékelési rutint egy Microsoft Office Excel munkafüzet tartalmazza, amelybe bemásolva saját adatainkat, a megírt függvények kiszámítják a magyar faktorsúlyok alapján a két dimenzió értékeit. ${ }^{1}$ Bár az egyénekhez rendelt transzcendencia és szimbolikusság értékek leginkább folytonos változókként korrelációszámításokhoz használhatók, javaslat olvasható arról, hogy mediánfelezésekkel az egyének a négy alskálának megfelelóen négy csoportba sorolhatóak. A transzcendencia változó esetében azok, akik a mediánon felüli értéket értek el, bevonják a transzcendenst, míg a medián alattiakra a transzcendencia elutasítása jellemző. A szimbolikusság esetében a medián felettiek szimbolikusan értelmezik a vallási tételeket, míg a medián alattiak szó szerint interpretálnak. Előnye, hogy mivel a korábbi magyar vizsgálatok eredményein alapuló faktorsúlyokkal dolgozik, ezért egymással összevethető eredményeket ad.

1 A kiértékelő algoritmust Dr. Martos Tamás bocsátotta a rendelkezésünkre 2015. 03. 22-én. 


\section{Eredmények}

A vallási attitúdformák előfordulási gyakorisága a KuVS alapján a következő: „ortodox” 21,8\%, ,külső kritika” 39,3\%, „relativizmus” 16,6\%, „második naivitás" 22,4\%. A külső kritika csoportjába a válaszadók szignifikánsan nagyobb arányban tartoznak, mint a többi csoportba. Életkor alapján az ortodoxia csoportja tér el jelentősen a többi csoporttól, ugyanis rájuk szignifikánsan magasabb életkor jellemző. Megvizsgáltuk a különbséget a férfiak és a nők között abban a tekintetben, hogy melyik vallási attitúdcsoportba tartoznak inkább. Az eredmények azt mutatják, hogy a férfiakra szignifikánsan nagyobb mértékben jellemző a külső kritika attitúdformája, mint a többi attitúdforma. A csoportok között jelentős volt a különbség abból a szempontból is, hogy mennyire tartják magukat vallásosnak. A relativisták mind a három csoporttól jelentősen eltértek, a vallásosság mértékét tekintve a többi csoporthoz képest középen helyezkedtek el. A külső kritika csoportja az összes többi csoporttól jelentősen alacsonyabb értéket adott az önbecsült vallásosságnál. Végül az ortodoxia és a második naivitás csoportja egymástól nem különbözött, viszont a másik két csoportnál szignifikánsan magasabb értéket vett fel, tehát ók tartották magukat a leginkább vallásosnak. Az eredményeket a 2. táblázatban részletezzük.

2. táblázat. A vallási attitúdcsoportok előfordulási gyakorisága és a csoportok összehasonlítása

a demográfiai változók és az önbecsült vallásosság mentén

\begin{tabular}{|c|c|c|c|c|c|c|c|c|}
\hline \multirow[t]{2}{*}{$\begin{array}{l}\text { Attitúdfor- } \\
\text { ma }\end{array}$} & \multicolumn{2}{|c|}{ Gyakoriság } & \multicolumn{2}{|c|}{ Életkor (év) } & \multicolumn{2}{|c|}{$\begin{array}{c}\text { Nemek \%-os } \\
\text { eloszlása }\end{array}$} & \multicolumn{2}{|c|}{$\begin{array}{l}\text { Önbecsült } \\
\text { vallásosság1 }\end{array}$} \\
\hline & fó & $\%$ & átlag & szórás & férfiak & nók & átlag & szórás \\
\hline Relativizmus & 51 & 16,6 & 27,8 & 14,1 & 15,0 & 17,3 & 2,9 & 1,7 \\
\hline $\begin{array}{l}\text { Második } \\
\text { naivitás }\end{array}$ & 69 & 22,4 & 26,3 & 10,5 & 19,0 & 24,0 & 5,2 & 1,4 \\
\hline Külső kritika & 121 & 39,3 & 26,0 & 13,7 & 51,0 & 33,7 & 2,3 & 1,5 \\
\hline Ortodoxia & 67 & 21,8 & 34,9 & 14,9 & 15,0 & 25,0 & 4,9 & 1,6 \\
\hline Összesen & 308 & 100,0 & 28,3 & 13,8 & 32,5 & 67,5 & 3,6 & 2,1 \\
\hline $\begin{array}{l}\text { A csoportok } \\
\text { össze- } \\
\text { hasonlítása }\end{array}$ & \multicolumn{2}{|c|}{$X^{2}(3)=36,052^{* * *}$} & \multicolumn{2}{|c|}{$\mathrm{F}(3,307)=7,219^{* * *}$} & \multicolumn{2}{|c|}{$X^{2}(3)=9,259^{*}$} & \multicolumn{2}{|c|}{$\mathrm{F}(3,307)=75,545^{* \star *}$} \\
\hline
\end{tabular}

Megjegyzés: ${ }^{1}$ Önbecsült vallásosság átlag: hétfokú skálán mennyire tartja magát vallásosnak az egyén. * $p<0,05 ;{ }^{* * *} p<0,001$. 
A 3. táblázat a négy attitúdformába tartozó személyek templomba járási gyakoriságát prezentálja. Khi-négyzet-próbával ellenőriztük az attitúdformák közti különbségeket és azt az eredményt kaptuk, hogy szignifikánsan összefügg a templomba járás gyakorisága azzal, hogy melyik csoportba tartoznak az egyének $\left(\chi^{2}(6)=106,835 ; p<0,001\right)$. A relativisták és a külső kritika csoportjába tartozók szignifikánsan ritkábban járnak templomba, mint a második naivitás és az ortodox csoport tagjai.

3. táblázat. A vallási attitűdformák és a templomba járás gyakoriságának összefüggései (fö)

\begin{tabular}{|c|c|c|c|c|c|c|c|c|}
\hline \multirow[t]{2}{*}{$\begin{array}{l}\text { Vallási } \\
\text { attitűdforma }\end{array}$} & \multicolumn{2}{|c|}{$\begin{array}{c}\text { Hetente vagy } \\
\text { hetente többször }\end{array}$} & \multicolumn{2}{|c|}{$\begin{array}{l}\text { Különleges } \\
\text { alkalmakkor }\end{array}$} & \multicolumn{2}{|c|}{$\begin{array}{l}\text { Szinte soha } \\
\text { vagy soha }\end{array}$} & \multicolumn{2}{|c|}{ Összesen } \\
\hline & fő & $\%$ & fó & $\%$ & fö & $\%$ & fó & $\%$ \\
\hline Relativizmus & 1 & 0,3 & 24 & 7,8 & 26 & 8,4 & 51 & 16,6 \\
\hline Második naivitás & 33 & 10,7 & 29 & 9,4 & 7 & 2,3 & 69 & 22,4 \\
\hline Külső kritika & 5 & 1,6 & 43 & 14,0 & 73 & 23,7 & 121 & 39,3 \\
\hline Ortodoxia & 27 & 8,8 & 32 & 10,4 & 8 & 2,6 & 67 & 21,8 \\
\hline Összesen & 66 & 21,4 & 128 & 41,6 & 114 & 37,0 & 308 & 100 \\
\hline
\end{tabular}

A vizsgálatban mért főbb változóink leíró adatait a 4. táblázatban foglaltuk össze.

4. táblázat. A vizsgálat főbb változóinak leíró adatai

\begin{tabular}{|l|c|c|c|c|}
\hline \multicolumn{1}{|c|}{ Változók } & Minimum & Maximum & Átlag & Szórás \\
\hline Éretlen elhárító mechanizmusok (REM-71) & 1,0 & 7,8 & 4,1 & 0,96 \\
\hline Érett elhárító mechanizmusok (REM-71) & 1,0 & 8,9 & 5,9 & 1,13 \\
\hline Szomatizáció (SCL-90-R) & 12,0 & 58,0 & 19,2 & 7,66 \\
\hline Transzcendencia (KuVS) & $-34,7$ & 39,8 & 2,1 & 16,82 \\
\hline Szimbolikusság (KuVS) & $-7,3$ & 18,5 & 7,3 & 5,00 \\
\hline
\end{tabular}

Mielőtt a transzcendencia és a szimbolikusság faktorokkal összefüggésben vizsgáltuk volna a fóbb változókat (elhárító mechanizmusok, szomatizáció), fel kívántuk tárni, hogy a négy vallásos attitúdformánál hogyan alakulnak az említett változók pontszámai. 
Az éretlen elhárító mechanizmusok csoportszintú különbségeit egyszempontos varianciaanalízissel teszteltük. A próba szignifikáns volt $(\mathrm{F}(3,307)=$ 10,905; $p<0,001)$, tehát a négy csoport átlagai között jelentős eltérés van, ezt szemlélteti a 4. ábra. A legmagasabb átlag (azaz az éretlen elhárítás legmagasabb pontszáma) a külső kritika csoportját jellemezte, utána következett az ortodox csoport, majd a relativizmus és végül a második naivitás csoportja. A páronkénti összehasonlítások alapján elmondható, hogy szignifikáns különbség a következő csoportok között volt jelen:

- második naivitás $<$ ortodox $(p=0,004)$

- második naivitás < külső kritika $(p<0,001)$

- relativizmus < külső kritika $(p=0,012)$.

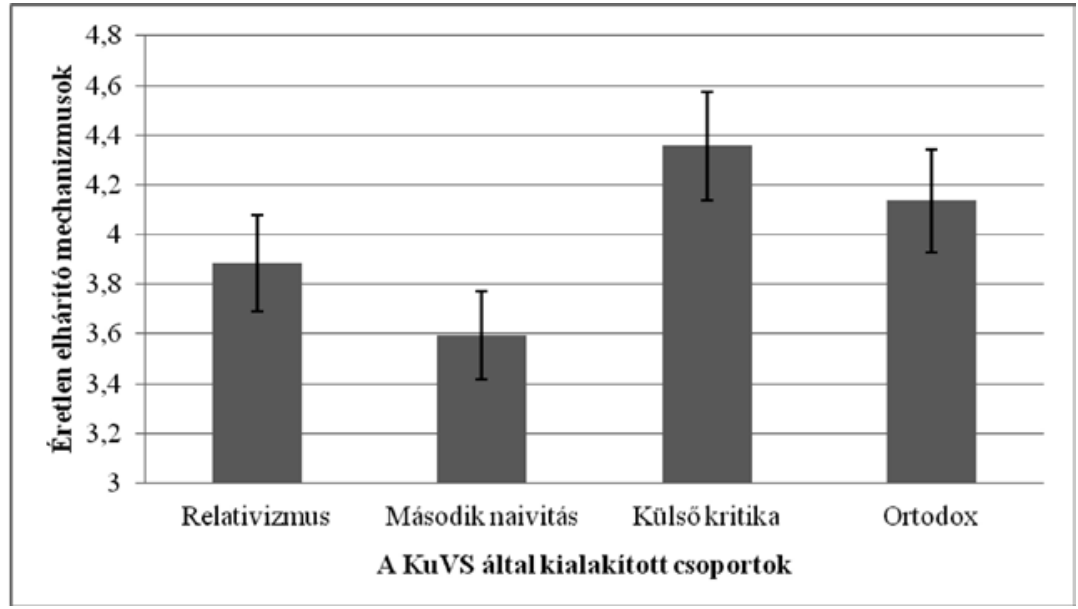

4. ábra. A vallási attitúd csoportok különbségei az éretlen elhárító mechanizmusok mentén

Megjegyzés: az ábrán feltüntettük az átlagok 95\%-os megbízhatósági intervallumát

Az érett elhárító mechanizmusokkal ugyanígy jártunk el, ám ebben az esetben az egyszempontos varianciaanalízis nem hozott szignifikáns eredményt $(F(3,307)=1,974 ; p=0,118)$, azaz nincs lényegi eltérés a négy csoport között abból a szempontból, hogy milyen mértékben használnak érett elhárító mechanizmusokat (lásd az 5. ábrát).

A szomatizáció pontszámának csoportonkénti eltéréseit vizsgáló egyszempontos varianciaanalízis szignifikáns eredményt hozott $(F(3,307)=4,764$; $p=0,003)$. A legmagasabb átlag az ortodox csoportnál volt (tehát náluk volt a legjelentősebb mértékú a szomatizáció), majd a külső kritika, a második 


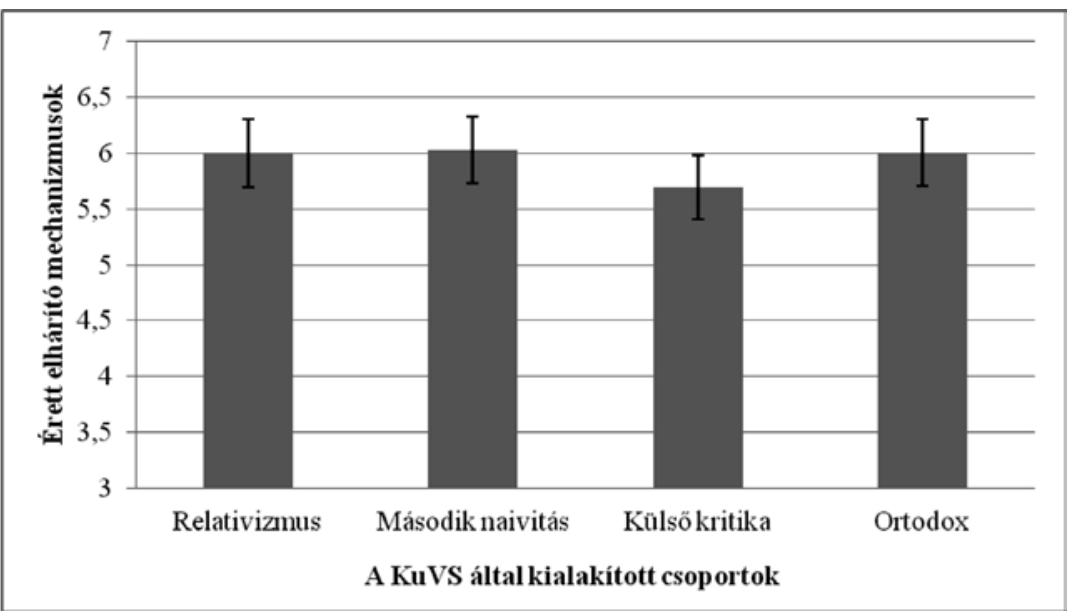

5. ábra. A vallási attitúd csoportok különbségei az érett elhárító mechanizmusok mentén

Megjegyzés: az ábrán feltüntettük az átlagok 95\%-os megbízhatósági intervallumát

naivitás és végül a relativizmus csoportja következett. A 6. ábrán látható oszlopdiagram prezentálja a csoportok eltéréseit. A post hoc tesztből kiderült az is, hogy pontosan mely csoportok között volt szignifikáns a különbség:

- relativizmus < külső kritika $(p=0,048)$

- második naivitás < külső kritika $(p=0,021)$

- második naivitás < ortodox $(p=0,043)$.

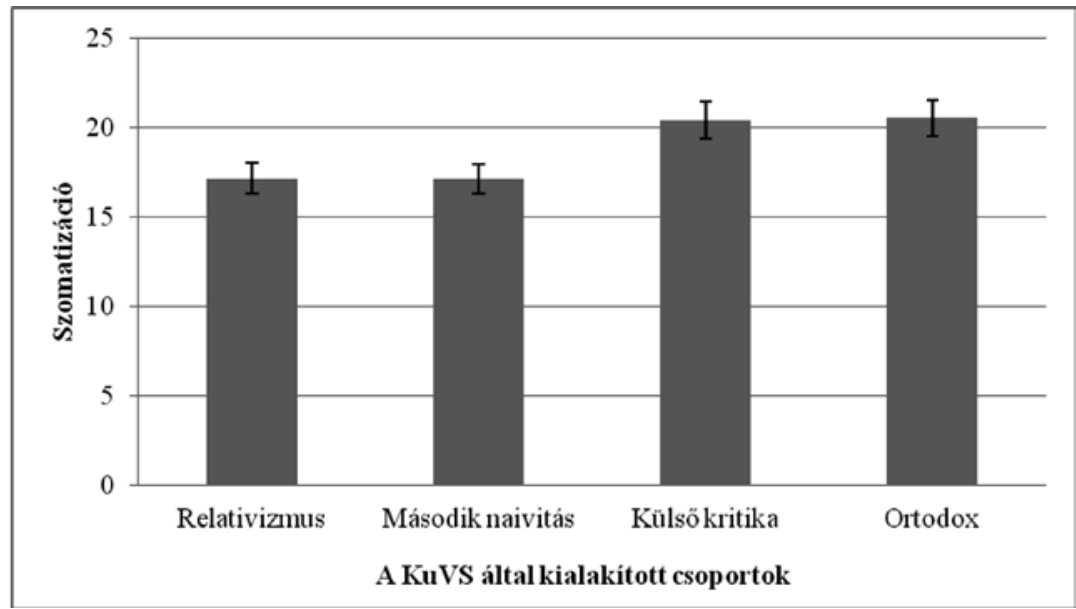

6. ábra. A vallási attitűd csoportok összehasonlítása a szomatizáció mentén Megjegyzés: az ábrán feltüntettük az átlagok 95\%-os megbízhatósági intervallumát 
A mediációs elemzés előtt megvizsgáltuk a változók közötti lineáris kapcsolatokat. A korrelációs elemzés eredményeit az 5. táblázatban mutatjuk be.

5. táblázat. A vizsgálat fóbb változóinak korrelációs táblázata

\begin{tabular}{|l|c|c|c|}
\hline & $\begin{array}{c}\text { Szomatizáció } \\
\text { (SCL-90-R) }\end{array}$ & $\begin{array}{c}\text { Transzcendencia } \\
\text { (KuVS) }\end{array}$ & $\begin{array}{c}\text { Szimbolikusság } \\
\text { (KuVS) }\end{array}$ \\
\hline $\begin{array}{l}\text { Éretlen elhárító } \\
\text { mechanizmusok (REM-71) }\end{array}$ & $0,45^{* *}$ & $-0,19^{* *}$ & $-0,25^{* *}$ \\
\hline $\begin{array}{l}\text { Érett elhárító } \\
\text { mechanizmusok (REM-71) }\end{array}$ & $-0,04$ & 0,07 & $0,19^{* *}$ \\
\hline Szomatizáció (SCL-90-R) & 1,00 & $-0,05$ & $-0,19^{* *}$ \\
\hline
\end{tabular}

Megjegyzés: ** $p<0,01$.

A táblázatból látható, hogy az első hipotézis (H1) - miszerint a vallásos tanok szimbolikusabb értelmezése több érett és kevesebb éretlen elhárító mechanizmussal jár együtt - alátámasztást nyert. Az összefüggések gyengék.

A második hipotézis (H2) is beigazolódott, hiszen a szimbolikusabb értelmezés valóban szignifikánsan alacsonyabb mértékú szomatizációval jár együtt, bár az összefüggés ezúttal is gyenge.

A következő hipotézis (H3) arra kereste a választ, hogy az előző hipotézisben feltételezett kapcsolatban a szimbolikusság és a szomatizáció között vajon az elhárító mechanizmusok mediáló szerepet töltenek-e be. Az 5. táblázatban közölt eredményekre alapozva mediációs elemzéseket végeztünk, hogy teszteljük az elhárító mechanizmusok közvetítő szerepét a szimbolikusság és a szomatizáció között. Ahogyan az a 7. ábrán látható, a szimbolikusság és a szomatizáció között nem mutatkozott szignifikáns közvetlen összefüggés $(\beta=-0,06 ; p=0,21)$. Szignifikáns, negatív irányú összefüggés mutatkozott ugyanakkor a szimbolikusság és az éretlen elhárító mechanizmusok között $(\beta=-0,25 ; p<0,01)$, valamint az éretlen elhárító mechanizmusok és a szomatizáció között $(\beta=-0,44 ; p<0,01)$ is. A szimbolikusság szomatizációra kifejtett indirekt hatása az éretlen elhárító mechanizmusokon keresztül a Sobel-teszt alapján szignifikáns $(\beta=-0,11 ; p<0,01$; Sobel Z $=-3,51 ; p<0,01)$. Az indirekt hatást bootstrap eljárással tesztelve (10000-es mintavétellel) az alábbi, 95\%-os konfidencia intervallumot kaptuk: -0,17 és -0,05. Ezek alapján az éretlen elhárító mechanizmusok mediálják a kapcsolatot a szimbolikusság és a szomatizáció között. A szomatizáció varianciájának 21\%-át magyarázzák a független változók $\left(\mathrm{R}^{2}=0,21 ; \mathrm{F}(3,304)=17,41\right.$; $p<0,001)$. A szimbolikusság szomatizációra gyakorolt teljes hatása $\beta=$ -0,17; $p<0,01$ volt. Ezzel szemben az érett elhárító mechanizmusok nem mediálták a szimbolikusság és a szomatizáció közötti kapcsolatot (a szimbolikusság indirekt hatásának mértéke az érett elhárító mechanizmusokon keresztül $\beta=-0,01 ; p=0,22$; Sobel $Z=-1,22 ; p=0,22)$. 


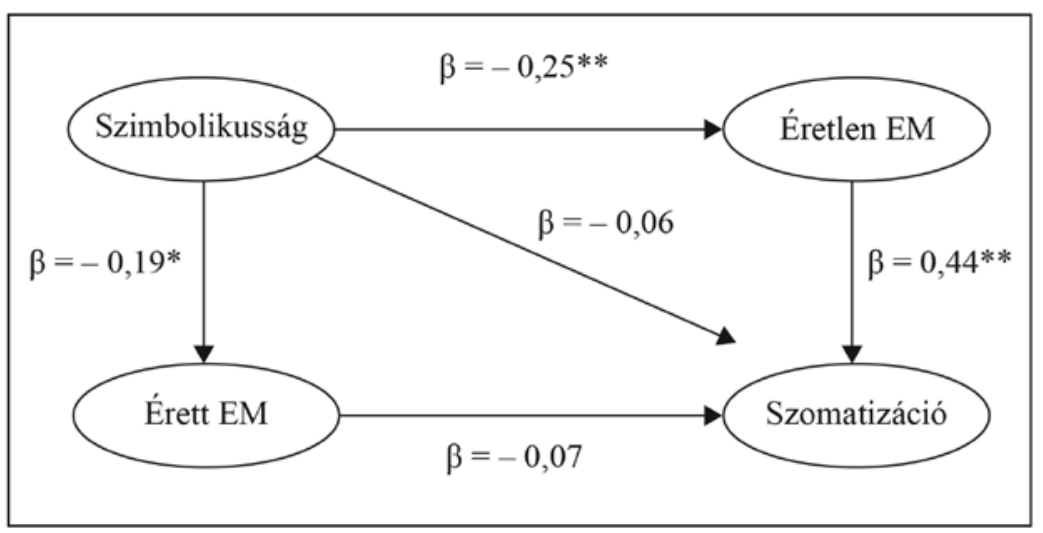

7. ábra. A szimbolikus értelmezésre való hajlam összefüggései az elhárító mechanizmusokkal és a szomatizációval (tapasztalati modell)

Megjegyzés: $\mathrm{EM}=$ elhárító mechanizmusok, * $p<0,05,{ }^{* *} p<0,01$

A negyedik hipotézis (H4), amely szerint a transzcendencia nagyobb mértékú bevonása több érett és kevesebb éretlen hárítással jár együtt, részben alátámasztást nyert. Valóban fennáll ugyanis az éretlen elhárító mechanizmusokkal a negatív irányú (ám gyenge) együttjárás, azonban az érett elhárító mechanizmusoknál nincs szignifikáns korreláció.

A transzcendencia nagyobb bevonásának kisebb mértékú szomatizációval való együttjárását feltevő hipotézis (H5) nem nyert alátámasztást, hiszen a két változó közötti kapcsolat nem szignifikáns.

Az utolsó hipotézist (H6), amely a transzcendens bevonását, a szomatizációt és az elhárító mechanizmusokat hozta összefüggésbe, nem teszteltük mediációs elemzéssel, mivel az 5. táblázatból látható, hogy a transzcendencia nem mutat összefüggést sem a szomatizációval, sem az éretlen elhárító mechanizmusokkal.

\section{Megbeszélés}

A bemutatott vizsgálat az elhárító mechanizmusok, a vallásosság különböző attitúdformái és a szomatizáció kapcsolatait igyekszik körbejárni. A felsorolt témák gyakorlati jelentősége röviden abban ragadható meg, hogy nagy embertömegeket érintenek. A reprezentatív Hungarostudy 2002 vizsgálat adatai alapján a magyar népesség 26\%-a számára nagyon fontos a vallás, 39\% számára kissé, míg 35\% számára a vallás egyáltalán nem fontos (Kopp, Székely, \& Skrabski, 2004). A lakosság negyede tehát erősen érintett a kér- 
désben. Nincs ez másképp a szomatizációval sem. Bár ebben az esetben sok szempontból nehezebb pontos becslést adni, a nagy populációkon végzett felmérések alapján általánosságban elmondható, hogy az orvosi rendelőket felkereső új ambuláns betegek 25-35\%-a dominánsan szomatoform panaszokkal érkezik (Kulcsár \& Rózsa, 2004). Az elhárító mechanizmusok kiemelt fontosságát pedig az jelzi, hogy felmérésük a DSM-IV-ben (1994) javasolt volt, mivel a páciens diagnózisának pontosítását szolgáló fontos adalékként tekintettek rá. Mindezeket egybevetve az említett témák kutatásra indokoltnak látszanak, mivel nem marginális, csekély jelentőségú, hanem széles rétegeket érintő jelenségekről van szó.

Vizsgálatunk fő célkitúzése az volt, hogy a vallásosságot, az elhárító mechanizmusokat és a szomatizációt - a korábbi vizsgálatokkal ellentétben ne külön-külön, hanem egyben is elemezzük és értelmezzük, illetve hogy mindezt egy olyan valláspszichológiai keretben tegyük, amely lehetóvé teszi a transzcendens bevonásának értékelésén túl az egyének szimbolikus / szó szerinti értelmezési fokának megragadását is.

A vallási attitúdformák előfordulási gyakorisága a Kritika Utáni Vallásosság Skála (KuVS; Hutsebaut, 1996; Horváth-Szabó, 2003) alapján a következőképpen alakult: az ortodox csoportba a 308 fős minta 21,8\%-a, a külső kritikához 39,3\%, a relativizmushoz 16,6\%, a második naivitáshoz pedig 22,4\% tartozott. A négy attitúdforma között szignifikáns eltérés mutatkozott mind az éretlen elhárító mechanizmusok használatában, mind pedig a szomatizáció mértékében.

A hipotézisvizsgálatok eredményeiből az látszik, hogy a vallásos tanok szimbolikus értelmezése gyenge pozitív együttjárást mutatott az érett elhárítással, az éretlen elhárítással pedig gyenge negatív irányú együttjárás állt fenn. Mindez összecseng Wulff (1997) érvelésével, amely szerint a vallásos képek minél szimbolikusabb úton történő értelmezése olyan személyiség jellemzője legtöbbször, aki nagy énerővel rendelkezik. A wulffi elmélet ismeretében talán azzal magyarázható a szimbolikusabban gondolkozók adaptívabb hárítási stílusa, hogy ezek a személyek jobban képesek az ellentmondásokat integrálni és így kevésbé használnak olyan neurotikus elhárító mechanizmusokat, mint például az elfojtás, amely az integrálhatatlan érzések elnyomásával dolgozik.

A korrelációvizsgálat alapján látható, hogy a vallásos tanok szimbolikusabb értelmezése gyenge negatív irányú együttjárást mutat a szomatizációs tünetek jelenlétével. A kapott adatok megerősítik Ryan és munkatársai (1993), illetve Salsman (2002) eredményeit, miszerint a belülről fakadó, átgondoltabb hitforma kevesebb szomatizációs tünettel mutat együttjárást, mint az eszközjellegú, kevésbé átgondolt hit. Vizsgálatunk csoportszintú összehasonlításából is kitúnt, hogy a külső kritika és az ortodoxia csoportja (tehát az a két csoport, amely a vallásos tanokat inkább szó szerint értelmezi) 
sokkal inkább mutat szomatizációs tendenciát, mint a két szimbolikusabban értelmező csoport (második naivitás, relativizmus). Magyarázhatjuk ezt olyan módon is, hogy azok a személyek, akik valamilyen okból kifolyólag többet szomatizálnak, olyan hitéletet élnek, ami kevésbé önmagáért való, inkább abban segít, hogy legyen egy biztos pont az életükben (Bergstrand, 1984; idézi Wikström, 2000), ami megvédi őket a testi tünetekből fakadó szorongástól, a szorongásból fakadó testi tünetektől, esetleg a szorongásekvivalens tünetektől. Az ok-okozati összefüggések pontosabb feltárásához azonban az eredményeink nem nyújtanak elég információt.

A mediációs elemzéssel arra kerestük a választ, hogy milyen módon változna a szimbolikus értelmezés és a szomatizációs tünetek kapcsolata, hogyha figyelembe vennénk az elhárító mechanizmusok esetleges közvetító hatását. Az elemzés eredményei arra mutattak rá, hogy a szimbolikusság és a szomatizáció közötti lineáris kapcsolat annak köszönhetó, hogy mindkét változó együttjár valamilyen módon az éretlen elhárító mechanizmusokkal: minél több éretlen elhárító mechanizmust használnak a személyek, annál kevésbé jellemző rájuk, hogy a vallásos tanokat szimbolikusan értelmezzék, és emellett annál több szomatizációs tünetet észlelnek. Schur (1955; idézi Mentzos, 2009) és Mitscherlich (1956; idézi Mentzos, 2009) elmélete alapján valószínúsíthető, hogy az éretlenebbül hárító, azaz éngyengébb személyek hajlamosabbak szorongásuk miatt testi tünetek megélésére. Mindemellett ezek az egyének nagyobb valószínúséggel tekinthetnek - tudattalanul a vallásra egyfajta eszközként, amellyel szorongásukat csökkenthetik. Mivel azonban vallásosságuk eszközjellegú, nem pedig önmagáért való, azaz céljellegú, ezért vélhetően a vallásosság éretlenebb fokán állnak és a vallásos tanokat kevésbé szimbolikusan interpretálják. Erről számol be Sundén (1966; idézi Wikström, 2000), Bergstrand (1984; idézi Wikström, 2000), illetve Wikström (2000) is: szerintük ugyanis a vallásosság fundamentalistább formája (ortodoxia) gyakran egyfajta eszköz, amely a szorongás eliminációját szolgálja. Tekintetbe véve, hogy nem klinikai (tehát nem diagnosztizált szomatizációs zavarral vagy pszichoszomatikus betegséggel küzdő) mintával dolgoztunk, a jövőben érdemes lenne kifejezetten ilyen minta bevonásával finomítani az eredményeinket. Az érett elhárító mechanizmusok esetében nem találtunk összefüggést, ennek lehetséges magyarázatát ld. lentebb.

A vallásosság általunk vizsgált másik faktora, a transzcendens bevonása az éretlen elhárítási módok kisebb mértékú használatával járt együtt. Mivel mindez egybehangzik Tari és munkatársai (2014) eredményeivel, illetve megfelel annak, amit Pargament (1997) és Siegel és munkatársai (2001) vizsgálatai alapján vártunk, úgy túnik, hogy a vallásosabb személyek összességében hatékonyabb szorongáscsökkentő eszközökkel bírnak, mint a nem hívők. A szakirodalomból ismert ennek magyarázata. Ilyen például, hogy a vallásos képek és rítusok szinte minden élethelyzetre megoldási sémát kínál- 
nak, mellyel előmozdítják az egyének sikeres alkalmazkodását (Levin, 1996; Wikström, 2000); illetve az is szorongáscsökkentő szereppel bírhat, hogy a hívő emberek az imádkozás és Istenben való hitük által úgy érezhetik, kontroll alatt tarthatnak egyébként kevésbé kontrollálható történéseket is (Levin, 1996; Siegel és mtsai, 2001). Az előfeltevéseknek ellentmondóan azonban az érett elhárító mechanizmusok és a transzcendencia bevonása között nem tapasztaltunk szignifikáns kapcsolatot. Ennek okát abban kereshetjük, hogy a vizsgálati személyek összességében meglehetősen magas érett elhárításpontszámot értek el. A jelenség bővebb magyarázatát ld. lentebb.

Konkrétan a szomatizáció és a transzcendensben való hit összefüggéseiról a szerzők tudomása szerint nem állnak rendelkezésre szakirodalmi adatok, azonban azt számtalan vizsgálat megerősítette, hogy a transzcendenst bevonó személyek általánosságban jobb egészségi állapotnak örvendenek, mint a nem hívők (Ellison \& Levin, 1998; Siegel és mtsai, 2001). Ebből kiindulva feltételeztük, hogy ez igaz lehet a szomatizációra is - azonban a transzcendensben való hit és a szomatizáció közt nem találtunk szignifikáns kapcsolatot. A szomatizáció tehát a vizsgálat eredményei alapján nem függ össze a vallási bevonódással, de még a szimbolikussággal való kapcsolata is inkább az éretlen elhárító mechanizmusok közvetító szerepével volt magyarázható.

Az eredmények alapján az is észrevehető, hogy az érett és az éretlen elhárító mechanizmusok nem egy dimenzió mentén helyezhetőek el, hanem inkább különálló jelenségekként múködnek, amelyek egymástól függetlenül variálódnak. Az egyének tehát vegyesen használják mindkét típusú elhárítást. Megfigyelhetó volt, hogy az érett elhárítás faktornál nem mutatkozott eltérés a négy vallási attitúdcsoport között, és következetesen magas értékeket értek el a személyek ezen a faktoron. A jelenség mögött a társas kívánatosság, illetve a pozitív énkép fenntartásának igénye is meghúzódhatott, mivel az érett elhárító mechanizmusok esetén valamivel könnyebben detektálható volt a normálisnak vagy szociálisan kívánatosnak tekintett válasz, mint az éretlen elhárító mechanizmusokhoz tartozó tételeknél. Például az érett elhárításhoz tartozó altruizmus egyik tétele így hangzik: „Szívesen segítek másoknak, nem számít, ha ez plusz erőfeszítésbe kerül”. Véleményünk szerint ennél a tételnél nyilvánvalóbb a szociálisan kívánatosabb válasz, mint például az éretlenebb idealizáció faktor következő tételénél: „Ismerek valakit, aki olyan bölcs és olyan képességei vannak, hogy minden problémát meg tud oldani". Ez utóbbi sokkal értéksemlegesebb állítás. Tény, hogy előnyösebb lenne egy olyan kérdőív használata, amelynél nem áll fenn ez a probléma, azonban az elhárító mechanizmusok mérése önmagában is kihívást jelentó feladat, és tudomásunk szerint nem áll rendelkezésre olyan teszt, mely a REM-71-nél megbízhatóbban mérné az érett és éretlen elhárító mechanizmusokat. 
Vizsgálatunk eredményeinek általánosíthatóságát korlátozza a hozzáférhetőségi mintavétel, illetve a keresztmetszeti kutatási elrendezés, amely nem teszi lehetóvé ok-okozati összefüggések feltárását. További kritikaként felmerülhet, hogy az eredmények érvényességi körét szúkíti az a tény, hogy a használt vallásosság skála tartalmilag kifejezetten a keresztény valláshoz fúződik, azonban Martos és munkatársai (2009) beszámolnak olyan eredményekről, miszerint minimális változtatással muszlim közösségekben is sikeresen adaptálták a kérdőívet. Ebből következően új perspektívát nyithat a jövőbeli kutatások előtt a különböző vallási közösségben való vizsgálódás lehetősége. További érdekes adatokkal szolgálhatna egy olyan vizsgálat, amelyben egy klinikai minta (pl. szomatizációs zavarral diagnosztizált egyének, pszichoszomatikus betegséggel élők) és egy kontrollcsoport összevetése történne.

Összefoglalva, a hipotézisvizsgálatok eredményei alapján úgy túnik, hogy a KuVS által mért két vallásos csoport (ortodoxia, második naivitás) között számottevő eltérések állnak fenn mind az elhárító mechanizmusok, mind pedig a szomatizáció kapcsán. Az ortodox csoport éretlenebbül hárítónak és többet szomatizálónak bizonyult, szemben a kevesebb éretlen elhárító mechanizmust használó és kevésbé szomatizáló második naivitás attitúdformájával. A szomatizáció azonban nem mutat direkt összefüggést a vallásos tanok szimbolikus/szó szerinti értelmezésével, hanem az elhárító mechanizmusok érettségével áll inkább kapcsolatban. Ezek alapján úgy túnik, hogy valóban van a vallásosságnak olyan formája (ortodox csoport), amely kevésbé adaptív szorongáscsökkentő módszerekkel jellemezhetó. Esetükben a vallásosságot tudattalan szorongáscsökkentő metódusnak is tekinthetjük, ami igazolja a vallásosság éretlenebb, kevésbé szimbolikus módját is. A második naivitás csoportja ezzel szemben absztraktabb, szimbolikusabb értelmezésmódot vall, ami abból eredhet, hogy nagyobb fokú énerejüknek köszönhetően vallásos hitük nem eszközjellegú, hanem önmagáért való.

\section{Irodalom}

Bergstrand, G. (1984). En illusion och dess utveckling - Om synen på religion i psykoanalytisk teori. Älvsjö: Verbum

BNO-10 (1996). BNO-10 zsebkönyv DSM-IV meghatározásokkal. Budapest: Animula

Cramer, P. (1998). Coping and defense mechanisms - What's the difference? Journal of Personality, 66(6), 919-946.

Derogatis, L.R., \& Cleary, P.A. (1977). Confirmation of the dimensional structure of the SCL-90 - A study in construct validation. Journal of Clinical Psychology, 33(4), 981-989.

Derogatis, L.R., Rickels, K., \& Rock, A.F. (1976). The SCL-90 and the MMPI - A step in the validation of a new self-report scale. British Journal of Psychiatry, 128, 280-289. 
Dezutter, J., Soenens, B., \& Hutsebaut, D. (2006). Religiosity and mental health - A further exploration of the relative importance of religious behaviors vs. religious attitudes. Personality and Individual Differences, 40(4), 807-818.

DSM-IV (1994). Diagnostic and statistical manual of mental disorders (4. ed.). Washington, DC: American Psychiatric Association

Ellison, C.G., \& Levin, J.S. (1998). The religion-health connection - Evidence, theory, and future directions. Health Education and Behavior, 25(6), 700-720.

Fontaine, J.R.J., Duriez, B., Luyten, P., \& Hutsebaut, D. (2003). The internal structure of the Post-Critical Belief scale. Personality and Individual Differences, 35(3), 501-518.

Gabbard, G.O. (2009). A hosszú pszichodinamikus pszichoterápia tankönyve. Budapest: Oriold és Társai Kiadó

Gardner, R.W., Holzman, P.S., Klein, G.S., Linton, H.B., \& Spence, D.P. (1959). Cognitive control - A study of individual consistencies in cognitive behavior. Madison: International Universities Press

Hayes, A.F. (2013). Introduction to Mediation, moderation and conditional process analysis. New York: Guilford Press.

Hoffmann, S.O., \& Hochapfel, G. (2000). Neuróziselmélet, pszichoterápia és pszichoszomatikus medicina. Budapest: Medicina

Horváth-Szabó, K. (2003). Hazai vizsgálatok a Kritika utáni vallásosságskálával. Magyar Pszichológiai Szemle, 58(1), 127-152.

Hutsebaut, D. (1996). Post-Critical Belief - A new approach to the religious attitude problem. Journal of Empirical Theology, 9(2), 48-66.

Hyphantis, T.N., Taunay, T.C., Macedo, D.S., Soeiro-de-Souza, M.G., Bisol, L.W., Fountoulakis, et al. (2013). Affective temperaments and ego defense mechanisms associated with somatic symptom severity in a large sample. Journal of Affective Disorders, 150(2), 481-489.

Kiss, E.Cs., Vajda, D., Káplár, M., Csókási, K., Hargitai, R., \& Nagy, L. (2015). A 25-itemes Connor-Davidson Rezíliencia Skála (CD-RISC) magyar adaptációja. Mentálhigiéné és Pszichoszomatika, 16(1), 93-113.

Kopp, M., Skrabski, Á., \& Székely, A. (2004). Vallásosság és egészség az átalakuló társadalomban. Mentálhigiéné és Pszichoszomatika, 5(2), 103-125.

Kulcsár, Zs., \& Rózsa, S. (2004) Hisztéria, szomatizáció és funkcionális stresszbetegségek. In Kulcsár, Zs., Rózsa, S., \& Kökönyei, Gy. (Szerk.), Megmagyarázhatatlan testi tünetek (11-47). Budapest: ELTE Eötvös Kiadó

Lazarus, R.S. (1993). From psychological stress to the emotions - A history of changing outlooks. Annual Review of Psychology, 44, 1-21.

Levin, J.S. (1996). How religion influences morbidity and health: Reflections on natural history, salutogenesis and host resistance. Social Science $\mathcal{E}$ Medicine, 43(5), 849-864.

Lipowski, Z.J. (1968). Review of consultation-liaison psychiatry and psychosomatic medicine, III. Theoretical issues. Psychosomatic Medicine, 30(4), 395-422.

Luban-Plozza, B., Pöldinger, W., \& Kröger, F. (1994). Pszichoszomatikus betegek az orvosi gyakorlatban. Budapest: Animula

Martos, T., Kézdy, A., Robu, M., Urbán, Sz., \& Horváth-Szabó, K. (2009). Újabb adatok a Kritika Utáni Vallásosság Skála alkalmazásához - Elmélet és módszertan. Magyar Pszichológiai Szemle, 64(4), 643-669.

Mentzos, S. (2009). A konfliktus-feldolgozás neurotikus módjai - Pszichoanalitikus neurózistan klasszikus és új megközelítésben. Budapest: Lélekben Otthon Kiadó

Mitscherlich, A. (1956). Krankheit als Konflikt. Frankfurt am Main: Suhrkamp

Pargament, K.I. (1997). The psychology of religion and coping - Theory, research, practice. New York: Guilford 
Ryan, R.M., Rigby, S., \& King, K. (1993). Two types of religious internalization and their relations to religious orientations and mental health. Journal of Personality and Social Psychology, 65(3), 586-596.

Salsman, J.M. (2002). The relationship between religiosity and psychological distress - A scale development strategy with the SCL-90-R. University of Kentucky Master's Theses. Paper 385. Letöltve: 2015. 04. 23-án: http://uknowledge.uky.edu/gradschool_theses/385

Schur, M. (1955). Comments on the metapsychology of somatisation. Psychoanalytic Study of the Child, 10, 119-164.

Siegel, K., Anderman, S.J., \& Schrimshaw, E.W. (2001). Religion and coping with healthrelated stress. Psychology and Health, 16(6), 631-653.

Steiner, H., Araujo, K.B., \& Koopman, C. (2001). The Response Evaluation Measure (REM-71) - A new instrument for the measurement of defenses in adults and adolescents. The American Journal of Psychiatry, 158(3), 465-473.

Sundén, H. (1966). Die Religion und die Rollen: eine psychologische Untersuchung der Frömmigkeit. Berlin: Walter de Gruyter

Tari, A.Z., Sobhi-Gharamaleki, N., Hojjati, A., \& Alian, B. (2014). Relationship between religious orientation and defense mechanisms in adolescents. Procedia-Social and Behavioral Sciences, 114, 287-290.

Unoka, Zs., Rózsa, S., Kő, N., Kállai, J., Fábián, Á., \& Simon L. (2004). A Derogatis-féle Tünetlista hazai alkalmazásával szerzett tapasztalatok. Psychiatria Hungarica, 19(3), 235-243.

V. Komlósi, A., \& Rózsa, S. (2001). Elhárítás, megküzdés, depresszió - Adatok és gondolatok a három jelenség kapcsolatáról - fejlődési vetületben. In Pléh, Cs., László, J., Oláh, A. (Szerk.), Tanulás, kezdeményezés, alkotás (337-351). Budapest: ELTE Eötvös Kiadó

V. Komlósi, A., \& Rózsa, S. (2002). Az elhárító mechanizmusok új szemlélete - Hazai tapasztalatok az elhárító mechanizmusok fejlődési alapú csoportjait elkülönítő új kérdőívvel. In A Magyar Pszichológiai Társaság XV. Országos Tudományos Nagygyúlése. Előadáskivonatok (99-107). Budapest: Magyar Pszichológiai Társaság

Wikström, O. (2000). A kifürkészhetetlen ember. Budapest: Animula Kiadó

Wise, M.G., \& Rundell, J.R. (2007). A pszichoszomatikus orvoslás klinikai kézikönyve - Útmutató a konzultációs-kapcsolati pszichiátriához. Budapest: Lélekben Otthon Kiadó

Wulff, D.M. (1997). Psychology of religion - Classic and contemporary. New York: John Wiley and Sons

\section{Köszönetnyilvánítás}

Köszönjük dr. Martos Tamásnak, hogy rendelkezésünkre bocsátotta a Kritika Utáni Vallásosság Skála kiértékelési rutinját. További köszönet illeti dr. V. Komlósi Annamáriát, amiért elérhetővé tette számunkra a dr. Rózsa Sándorral közösen írt Az elhárító mechanizmusok új szemlélete címú előadásuk kivonatát.

\section{Szerzói munkamegosztás}

Terdik Éva: irodalomkutatás, hipotézisek kidolgozása, adatgyújtés lefolytatása, statisztikai elemzések, eredmények értelmezése, kézirat megszövegezése. Sztancsik Veronika: szakmai vezető, irodalomkutatás, hipotézisek kidolgozása, eredmények értelmezése, kézirat megszövegezése. Dr. Papp Gábor: statisztikai elemzések, módszertani segítség. 


\title{
Nyilatkozat érdekütközésról
}

A szerzők ezúton kijelentik, hogy esetükben nem állnak fenn érdekütközések.

\section{Relationship between defense mechanisms, religiosity and somatization}

\author{
TERDIK, ÉVA - PAPP, GÁBOR - SZTANCSIK, VERONIKA
}

Background: Recent psychological studies treat religiosity as a coping mechanism in association with dealing with diseases. In many cases, religiosity was not even not associated with disease adaptation, but also had a negative correlation with it, though this phenomenon received less attention in the reports. We assumed, that the impact ascribed to maladaptive coping by the above-mentioned studies is actually in connection with the defence mechanisms. Aim: The aim of the study was to verify the relationship between religiosity and defence mechanisms, and also to include somatisation, a phenomenon closely related to the immature defence mechanisms. Methods: 308 respondents participated in the cross-sectional survey research $(32.5 \%$ male, $67.5 \%$ female, $\mathrm{M}=28.29$ years; $\mathrm{SD}=13.82$ years; $\min =14$ years; $\max =81$ years). Religious attitudes have been measured by the Post-Critical Belief Scale, defence mechanisms have been measured by REM-71, and somatization has been measured by the Somatization Scale of the SCL-90-R. Results: Frequency of occurrence of the four religious attitude types are: "orthodox" $21.8 \%$, „external critique” 39.3\%, „relativism” 16.6\%, „second naiveté” 22.4\%. Main results show significant differences between the four religious attitudes of the Post-Critical Belief Scale in the use of immature defence mechanisms $(\mathrm{F}(3,307)=10.905, p<0.001)$ and in the level of somatization $(\mathrm{F}(3,307)=4.764, p=0.003)$. The connection between somatization and symbolism is due to the mediating effect of immature defence mechanisms $(\beta=-0.11, p<$ $0.01)$. Conclusions: In the religious category, we can separate two groups with different features: the "orthodox" group, who use more immature defence mechanisms and can be characterized by higher level of somatization, and the "second naiveté" group, who use less immature defence mechanisms and is characterized by lower level of somatization. These results draw attention to the importance of considering religiosity in a more complex way for those who work in human services. Detecting immature defence mechanisms should be more emphasized helping the "orthodox" group to attain a more symbolical elaboration when dealing with psychological problems.

Keywords: defense mechanisms, religious attitudes, somatization, Post-Critical Belief Scale 